\title{
SENSITIVITAS GENDER GURU SEKOLAH DASAR DI KOTA SURAKARTA
}

\author{
Siany Indria Liestyasari \\ Program Studi Pendidikan Sosiologi-Antropologi \\ Universitas Sebelas Maret (UNS) \\ Email: sianyliestyasari@gmail.com
}

\begin{abstract}
Abstrak
Artikel ini mengkaji isu sensivitas gender di kalangan guru Sekolah Dasar (SD) dikaitkan dengan pendidikan keadilan gender di Surakarta. Sejak meratifikasi konvensi CEDAW, negara memiliki kewajiban untuk menyediakan proteksi kepada warga Negara Indonesia, khususnya perempuan dalam segala aspek kehidupan, termasuk pendidikan di dalamnya. Peran guru sebagai pendidik memiliki peran penting dalam proses menumbuhkan pendidikan adil gender yang bermula dari lingkungan sekolah. Penelitian ini menemukan bahwa pemahaman konsep gender dari para informan memiliki tafsir yang beraneka ragam. Akan tetapi mereka menerapkan pendidikan adil gender di dalam ruang kelas dengan pemahaman bahwa seorang guru tidak boleh membeda-bedakan antara laki-laki dan perempuan. Karena pemahaman konsep gender tidak komprehensif, penerapan pendidikan gender yang fair terbatas hanya pada masalah perlakuan kesetaraan untuk laki-laki dan perempuan.
\end{abstract}

Kata kunci: Sensitifitas Jender, Pendidikan, Profesionalisme Guru

\begin{abstract}
This article studies the issue of gender sensitivity in Elementary School teacher relations with gender equitable education in Surakarta. Since the ratification of CEDAW Convention, State has obligation to provide protection to Indonesian citizens, specifically women in all aspects of life, including the education. The role of teachers as educators is the main thing in the embodiment of gender equitable education that began at the school. This research finds that the understanding of gender concepts from informants varies greatly, but it all comes down to differences between men and women who are his base is merely a biological concept. This concept is actually reinforce gender stereotypes. But they have to apply gender equitable education in the classroom, with the understanding that as a teacher they are not entitled to differentiate between boys and girls. Because understanding the concept of gender that is not comprehensive, the gender fair education applications limited only to the problem of equality of treatment for boys and girls.
\end{abstract}

Keywords: Gender sensitivity, Education, and Teacher Profesionalism

\section{Latar Belakang}

Kemajuan pendidikan yang sangat pesat menjadikan bangsa yang terdidik dan berkualitas lebih percaya diri menghadapi kehidupan yang semakin kompetitif dan bersifat global. Di pundak pendidikanlah, masyarakat dibekali perangkap sikap, cara pandang dan nilai-nilai yang relevan untuk masa mendatang. Pendidikan, dengan demikian sudah seharusnya secara konseptual terbuka bagi transformasi nilai-nilai baru, yang membebaskan dan tidak membelenggu. Bagi Paulo Freire pendidikan merupakan alat perjuangan kelas 
sekaligus alat yang digunakan untuk membebaskan; dalam istilahnya muncul kemudian apa yang disebut memanusiakan manusia lewat pendidikan.

Sejalan dengan hal tersebut maka kembalilah ingatan kita pada sosok Kartini yang berjuang untuk bangsa Indonesia dan perempuan supaya memperoleh pendidikan yang setara dengan laki-laki. Pendidikan bagi Kartini merupakan suatu alat untuk melepaskan ketergantungan kaum perempuan terhadap laki-laki baik secara ekonomis maupun secara kultural. Artinya, pendidikan bagi Kartini adalah dengan mengenyam bangku sekolah yang nantinya akan berimplikasi pada perubahan kedudukan perempuan di masyarakat.

Pembedaan peran antara laki-laki dan perempuan dalam konteks masyarakat Jawa terus menerus disosialisasikan sejak kanak-kanak baik itu di lingkungan keluarga maupun sekolah dan masyarakat. Dengan demikian ada semacam keharusan sosial bagi laki-laki dan perempuan untuk berperilaku sesuai dengan peran yang dikonstruksikan oleh budaya masyarakat setempat yakni budaya patriarchal yang akhirnya melahirkan kesenjangan gender.

Kesenjangan gender juga banyak terjadi di bidang pendidikan. Data dari Dispora Kota Surakarta tahun 2006 menyebutkan bahwa ada sejumlah 18.615 orang berusia 5 tahun ke atas yang tidak bisa baca tulis, diantaranya sejumlah 5.037 laki-laki dan 13.578 perempuan. Secara general angka partisipasi sekolah perempuan masih rendah, misalnya angka tidak sekolah lagi di setiap jenjang pendidikan masih didominasi oleh anak perempuan. Fakta mengenai nilai anak perempuan yang berbeda dengan anak laki-laki membuat stereotipe negatif tentang anak perempuan. Bahkan usia tidak sekolah lagi bagi perempuan berada di level yang masuk dalam kategori wajib belajar 9 tahun di level pendidikan menengah. Usia dimana seharusnya mereka masih mengenyam pendidikan.

Pelestarian budaya gender juga masih terbaca apabila kita melihat isi kurikulum pendidikan sekolah, terutama di tingkat dasar yang juga menunjukkan adanya kekentalan dalam pembedaan gender. Buku-buku teks pelajaran di sekolah misalnya menggabarkan kegiatan ibu dan bapak secara berbeda, ibu biasanya digambarkan tinggal di rumah, memasak, mengasuh anak, dan kalaupun ke luar rumah sekedar berbelanja ke warung atau pasar; sementara bapak pergi ke kantor. Dalam buku pelajaran itu anak laki-laki digambarkan dengan kegiatan fisik yang aktif dan mobil, sebaliknya anak perempuan dengan gambaran aktivitas fisik yang cenderung lebih pasif (Rajab, 2005:56).

Melihat persoalan tersebut maka dalam konteks pendidikan di sekolah seorang guru memegang peranan penting sebagai sosok yang bisa membuat kesenjangan gender bisa dieliminir atau bahkan dilestarikan. Guru adalah mereka yang menghabiskan waktu bersama anak-anak di sekolah. Melalui guru—dan pendidikan di sekolah—anak-anak belajar untuk 
menghargai perbedaan gender. Melalui guru biasanya sosialiasi nilai-nilai kultural suatu masyarakat dilakukan. Untuk itulah penting kiranya usaha pemerintah melalui PUG untuk mulai merambah bidang pendidikan sebagai upaya mewujudkan pendidikan adil gender bagi masyarakat. Pendidikan ini dimulai dari anak-anak sekolah dasar yang nantinya akan berlanjut pada masyarakat. Sehubungan dengan hal tersebut maka peran serta guru dalam menghapuskan kesenjangan gender adalah hal penting yang tidak bisa dipandang dengan sebelah mata.

Artikel ini didasarkan pada hasil penelitian yang dilakukan di Kota Surakarta pada tahun 2008 dengan pertimbangan bahwa kota Surakarta merupakan sebuah kota yang memiliki Biro Pemberdayaan Perempuan di jajaran SKPD Kota Surakarta dan juga memiliki berbagai macam lembaga swadaya masyarakat yang memfokuskan pekerjaannya pada persoalan gender di masyarakat Surakarta. Dengan menggunakan analisa gender maka persoalan pendidikan di Kota Surakarta yang berkaitan dengan sensitivitas gender guru bisa teridentifikasi berikut penyebabnya..

\section{Persoalan Gender dalam Bidang Pendidikan di Kota Surakarta}

Persoalan gender dalam bidang pendidikan, salah satunya adalah akses dan pemerataan pendidikan, bisa dilihat dari angka partisipasi sekolah penduduk melalui tabel berikut ini.

Tabel 1. Jumlah Penduduk Usia Sekolah menurut Partisipasi Sekolah dan Jenis Kelamin di Kota Surakarta Tahun 2007

\begin{tabular}{|c|l|c|c|c|}
\hline \multirow{2}{*}{$\begin{array}{c}\text { Umur } \\
\text { sekolah }\end{array}$} & \multicolumn{1}{|c|}{ Partisipasi sekolah } & Jenis Kelamin & \multirow{2}{*}{ Total } \\
\cline { 2 - 5 } & Tdk/ belum pernah sekolah & - & - & - \\
\hline \multirow{3}{*}{$7-12$} & Masih sekolah & 24.804 & 26.500 & 51.304 \\
\cline { 2 - 5 } & Tdk sekolah lagi & 212 & 212 & 424 \\
\hline \multirow{2}{*}{ Jumlah Penduduk Usia 7 - 12 tahun } & $\mathbf{2 5 . 0 1 6}$ & $\mathbf{2 6 . 7 1 2}$ & $\mathbf{5 1 . 7 2 8}$ \\
\hline \multirow{3}{*}{$13-15$} & Tdk/ belum pernah sekolah & 424 & & 424 \\
\cline { 2 - 5 } & Masih sekolah & 12.932 & 11.024 & 23.956 \\
\cline { 2 - 5 } & Tdk sekolah lagi & 1.484 & 1.060 & 2.544 \\
\hline \multirow{2}{*}{ Jumlah Penduduk Usia 13 - 15 tahun } & $\mathbf{1 4 . 8 4 0}$ & $\mathbf{1 2 . 0 8 4}$ & $\mathbf{2 6 . 9 2 4}$ \\
\hline \multirow{3}{*}{$16-18$} & Tdk/ belum pernah sekolah & - & - & - \\
\cline { 2 - 5 } & Masih sekolah & 11.024 & 12.720 & 23.744 \\
\cline { 2 - 5 } & Tdk sekolah lagi & 2.120 & 3.392 & 5.512 \\
\hline \multirow{2}{*}{ Jumlah Penduduk Usia 16 - 18 tahun } & $\mathbf{1 3 . 1 4 4}$ & $\mathbf{1 6 . 1 1 2}$ & $\mathbf{2 9 . 2 5 6}$ \\
\hline \multirow{3}{*}{$19-24$} & Tdk/ belum pernah sekolah & 424 & & 424 \\
\cline { 2 - 5 } & Masih sekolah & 11.448 & 8.692 & 20.140 \\
\cline { 2 - 5 } & Tdk sekolah lagi & 15.900 & 19.716 & 35.616 \\
\hline \multicolumn{2}{|c|}{ Jumlah Penduduk Usia 19 - 24 tahun } & $\mathbf{2 7 . 7 7 2}$ & $\mathbf{2 8 . 4 0 8}$ & $\mathbf{5 6 . 1 8 0}$ \\
\hline
\end{tabular}

Sumber : Kota Surakarta dalam Angka Tahun 2007 
Partisipasi sekolah merupakan suatu indikator yang mengukur bagaimana tingkat keterlibatan masyarakat dalam hal pendidikan. Partisipasi sekolah di kota Surakarta menunjukkan secara umum bahwa angka jumlah perempuan yang tidak sekolah lagi lebih besar perbandingannya dengan jumlah laki-laki. Persoalan perbedaan angka ini bukan hanya disebabkan karena berbedanya jumlah penduduk laki-laki dan perempuan dimana perempuan memang jumlahnya lebih besar dibandingkan laki-laki. Namun persoalan budaya yang lebih mementingkan pendidikan untuk anak laki-laki juga masih kuat terasa. Hal ini memiliki implikasi yang tidak sederhana.

Putus sekolahnya anak perempuan dalam usia-usia yang seharusnya mereka masih mengenyam pendidikan akan menjadikan perempuan sebagai penduduk yang termasuk dalam kategori berpendidikan rendah. Pendidikan yang rendah akan menyulitkan mereka untuk mengakses pekerjaan-pekerjaan formal. Dengan demikian maka perempuan hanya akan bisa mengisi pekerjaan sector informal dengan gaji yang rendah. Implikasi selanjutnya adalah kualitas kehidupan yang rendah karena pendapatan yang mereka hasilkan tidak memadai.

Tabel 2. Penduduk Usia 5 tahun ke atas Menurut Pendidikan Tertinggi yang ditamatkan di Kota Surakarta Tahun 2007

\begin{tabular}{|l|r|r|r|}
\hline \multirow{2}{*}{ Pendidikan Tertinggi } & \multicolumn{2}{|c|}{ Jenis Kelamin } & \multirow{2}{*}{ Jumlah } \\
\cline { 2 - 3 } & Laki-Laki & Perempuan & \multicolumn{1}{|c|}{} \\
\hline Tidak punya ijasah SD & 35.616 & 40.068 & 75.684 \\
\hline SD & 40.704 & 51.092 & 91.796 \\
\hline SMP Umum/Kejuruan & 42.824 & 43.248 & 86.072 \\
\hline Madrasah Tsanawiyah & 212 & 636 & 848 \\
\hline SMU & 49.820 & 42.824 & 92.644 \\
\hline Madrasah Aliyah & 1.696 & 636 & 2.332 \\
\hline SMK & 19.080 & 20.988 & 40.068 \\
\hline DI/II & 2.120 & 4.028 & 6.148 \\
\hline DIII/sarmud & 9.752 & 8.692 & 18.444 \\
\hline DIV/S1 & 16.112 & 12.296 & 28.408 \\
\hline S2/S3 & 1.696 & 636 & 2.332 \\
\hline & 219.632 & 225.144 & 444.776 \\
\hline
\end{tabular}

Sumber : Kota Surakarta Dalam Angka Tahun 2007

Perbedaan gender juga bisa teramati dalam tabel di atas yakni tentang jumlah penduduk menurut pendidikan tertinggi yang ditamatkan. Secara umum, jumlah penduduk perempuan akan semakin sedikit jumlahnya seiring dengan tingginya tingkat pendidikan yang ditamatkan, dan ini berbanding terbalik dengan penduduk laki-laki yang semakin besar jumlahnya seiring dengan semakin tingginya tingkat pendidikan. Artinya, semakin sedikit perempuan yang bisa mengakses pendidikan tinggi setingkat Universitas. Hal ini juga mengindikasikan banyaknya penduduk perempuan yang putus sekolah. 
Rendahnya tingkat pendidikan bagi perempuan bisa disebabkan oleh berbagai macam hal. Namun implikasi yang bisa dirasakan adalah minimnya perempuan yang bisa berkiprah di sector public dibandingkan dengan laki-laki karena kurangnya kemampuan yang dimiliki. Persoalan rendahnya tingkat pendidikan juga bermuara pada persoalan selanjutnya yang menyangkut kehidupan perempuan.

Perempuan, dalam konsep peran jenis kelamin secara kodrat, struktur anatomi memungkinkan mereka untuk melaksanakan fungsi reproduksi yang tidak dapat dilakukan oleh laki-laki. Berdasarkan teori rekonstruksi sosial, fun gsi reproduksi ini diperluas ke tugastugas domestic di dalam rumah tangga, seperti membesarkan anak, mencuci dan memasak. Konstruksi sosial ini telah menimbulkan gejala diskriminasi terhadap perempuan yang menyebabkan mereka kurang berdaya dalam domain public. Akibatnya, perempuan menjadi segmen masyarakat yang secara ekonomis kurang produktif. Lebih jauh akan mengakibatkan kualitas hidup relative perempuan menjadi lebih rendah yang selanjutnya akan mengakibatkan rendahnya kualitas anak dan masa depan masyarakat (Ace Suryadi, 2004:11).

Persoalan tersebut juga harus dicermati dari berbagai angka statistik yang menyebutkan posisi pencapaian perempuan dalam bidang pendidikan. Salah satunya adalah tabel kemampuan membaca berikut ini.

Tabel 3. Penduduk Usia 5 tahun ke atas menurut Kemampuan Baca Tulis di Kota Surakarta Tahun 2007

\begin{tabular}{|l|r|r|r|}
\hline \multirow{2}{*}{ Kemampuan baca Tulis } & \multicolumn{2}{|c|}{ Jenis Kelamin } & \multirow{2}{*}{ Jumlah } \\
\cline { 2 - 3 } & \multicolumn{1}{|c|}{ Laki-Laki } & \multicolumn{1}{|c|}{ Perempuan } & \multicolumn{1}{c|}{} \\
\hline Huruf latin & 183.804 & 192.708 & 376.512 \\
\hline Huruf lainnya & 636 & 1.060 & 1.696 \\
\hline Latin dan huruf lainnya & 36.252 & 36.888 & 73.140 \\
\hline Tidak dapat & 6.360 & 21.200 & 27.560 \\
\hline Jumlah & $\mathbf{2 2 7 . 0 5 2}$ & $\mathbf{2 5 1 . 8 5 6}$ & $\mathbf{4 7 8 . 9 0 8}$ \\
\hline
\end{tabular}

Sumber : Kota Surakarta Dalam Angka Tahun 2007

Persoalan gender lainnya dalam bidang pendidikan diantaranya bisa dilihat dari tabel di atas yakni persoalan buta huruf. Angka melek huruf merupakan salah satu komponen Index Pembangunan Manusia sehingga apabila masih terdapat banyak angka buta huruf di suatu daerah maka HDI daerah tersebut akan rendah. Selain itu, dalam pengukuran Gender Development Index, melek huruf dan tingkat pendidikan pada perempuan menjadi salah satu komponen atau ukuran.

Dari tabel kemampuan membaca penduduk yang tertera di atas maka apabila dicermati maka jumlah angka buta huruf-yakni tidak dapat membaca-masih didominasi oleh penduduk perempuan yakni sebesar 21.200 orang, sementara penduduk laki-laki hanya 
sebesar 6.360 orang. Perbedaan ini bahkan hampir mencapai dua setengah kali lipat besarnya. Jumlah penduduk yang tidak memiliki kemampuan membaca akan berimplikasi pada kemampuan aksesnya pada pekerjaan. Logikanya, pekerjaan rendah berupah kecil merupakan pekerjaan yang bisa diakses oleh mayoritas masyarakat dengan kemampuan SDM yang rendah, salah satunya adalah kemampuan baca tulis. Apabila banyak jumlah perempuan yang menempati posisi tidak memiliki kemampuan membaca maka SDM perempuan juga rendah. Lagi-lagi, aksesnya terhadap pekerjaan formal menjadi sulit. Implikasi selanjutnya adalah tingkat kesejahteraan perempuan yang relative lebih rendah. Persoalan ini merupakan suatu kesenjangan gender.

Akibat kesenjangan pendidikan menurut gender, perempuan yang terdiri atas setengah penduduk dunia masih merupakan segmen masyarakat yang belum diberdayakan sehingga kurang produktif. Kesenjangan gender di bidang pendidikan dianggap merupakan pelanggaran terhadap hak-hak asasi manusia yang perlu dieliminasi melalui upaya-upaya yang sistematis dan terprogram. Oleh karena itu, setiap Negara termasuk Indonesia, telah mencanagkan komitmennya untuk mengurangi kesenjangan gender di bidang pendidikan. Komitmen tersebut dipertegas di dalam kesepakatan Dakkar dalam bentuk sasaran-sasaran kuantitatif yang harus dicapai dalam suatu kurun waktu tertentu oleh setiap Negara agar mencapai kesetaraan gender pada semua jenis dan jenjang pendidikan.

Berdasarkan hasil wawancara dalam penelitian ini maka sebagian besar informan tidak mengetahui apa persoalan gender dalam bidang pendidikan, khususnya di kota Surakarta. Para informan yang notabene adalah seorang guru tidak mengetahui berapa perkiraan jumlah penduduk perempuan dan laki-laki yang masih buta huruf, angka partisipasi sekolah di setiap kelompok umur bagi laki-laki dan perempuan serta tingkat pendidikan tertinggi yang ditamatkan oleh laki-laki dan perempuan. Seperti yang diungkapkan oleh seorang informan;

"Kalau angka ya jelas tidak tahu, BPS kota lebih tahu tentang hal tersebut. Kami hanya tahu misalnya jumlah anak-anak yang tidak lulus berapa, laki-laki berapa perempuan berapa, itupun jumlah di sekolah sendiri. Kalau ditanya jumlah buta huruf ya nggak tahu, tapi jaman sekarang mungkin masih ada yang buta huruf tapi kan jumlahnya saya rasa tidak terlalu besar. Kalau partisipasi sekolah saya rasa sekarang perempuan juga banyak yang bersekolah kok, bahkan sampai jenjang universitas, mereka juga pintar-pintar bahkan lebih pintar dari anak laki-laki lho mbak?" (Pak M).

Pemahaman gender seringkali hanya diartikan sempit sebagai persoalan perempuan, sehingga persoalan gender lebih cenderung dipahami sebagai persoalan perempuan. Memang benar bahwa kecenderungan masyarakat yang mengedepankan ideology bias gender 
seringkali akan mengakibatkan perempuan terdiskriminasi dan termarginalkan. Artinya perempuan lebih sering menjadi korban karena ketimpangan gender. Namun hal ini bukan berarti laki-laki pun tidak menjadi korban dari struktur masyarakat yang bias gender. Seringkali laki-laki terabaikan dan dituntut untuk selalu bisa melakukan segala hal.

Analisa dari Ismi Dwi \& Rutiana (2007:20) menyebutkan bahwa ada banyak persoalan yang dapat timbul pada anak-anak ataupun orang dewasa, yang sebenarnya berakar di dalam bias gender yang ditanamkan sejak kanak-kanak. Sebagai contoh, banyak anak lakilaki (murid) kalah prestasinya dari murid perempuan karena mereka lebih banyak bermain dan kurang belajar. Hal ini adalah akibat pelabelan gender bahwa anak laki-laki boleh bebas bermain di luar rumah, sedangkan anak perempuan harus banyak di rumah (sehingga waktu untuk belajar lebih besar).

Berdasarkan FGD (Focus Group Discussion) dengan beberapa LSM pemerhati perempuan di Surakarta, diperoleh keterangan bahwa pendidikan adil gender memang belum sepenuhnya diterapkan di sekolah-sekolah di Surakarta, baik itu di kalangan pendidikan dasar maupun menengah. Nuansa kultur masyarakat yang patriarkal disebut-sebut sebagai salah satu gejala sulitnya mengintegrasikan perspektif gender dalam kegiatan belajar mengajar di sekolah. Terlebih apabila pendidik belum memiliki pemahaman yang kuat akan gender sehingga sensitivitas yang dimilikinya pun belum responsive gender. Apabila pendidikan adil gender akan menguat di Surakarta maka hal yang harus dilakukan adalah memberikan konsep gender terhadap para pendidik termasuk stake holder yang mengendalikan pendidikan di Surakarta.

\section{Sensitivitas Gender Guru Sekolah Dasar di Surakarta}

Persoalan gender juga termasuk di dalamnya bagaimana sensitivitas yang dimiliki oleh pengajar maupun stake holder dalam bidang pendidikan, misalnya kepala sekolah yang kemudian ikut memberikan kontribusi dalam terwujudnya kesetaraan gender di lingkungan sekolah. Sensitivitas yang dimiliki baik oleh para pejabat bidang pendidikan maupun oleh kepala sekolah di tingkatan yang paling riil pada akhirnya juga turut menentukan bagaimana persoalan gender bisa diminimalkan dalam masyarakat. Stake holder yang responsive gender tersebut akhirnya yang akan melahirkan kebijakan-kebijakan sekolah yang responsive gender sehingga melahirkan kesetaraan gender.

Sensitivitas merupakan paham tidaknya seseorang terhadap konsep gender (secara umum) yang selanjutnya mengarah pada peka tidaknya seseorang terhadap persoalan gender. Seorang guru yang sensitive gender akan dengan tanggap membedakan persoalan anak 
didiknya di dalam kelas. Dengan demikian dia akan dapat mencari solusi yang responsive gender berkaitan dengan persoalan yang dihadapinya. Namun, sensitivitas memang harus dimulai dengan kemampuan seseorang untuk memahami konsep dan persoalan gender baru kemudian orang tersebut mampu mengaplikasikannya dalam tindakan dan perilaku keseharian.

Enam orang guru SD yang menjadi informan (masing-masing tiga orang laki-laki dan tiga orang perempuan) dalam penelitian ini memiliki pemahaman yang berbeda tentang konsep dan persoalan gender. Artinya mereka mengartikan gender dalam definisi yang berbeda-beda meskipun muaranya sama. Beberapa diantaranya, terutama informan laki-laki mengaku bahwa mereka belum pernah mengikuti pelatihan gender baik itu yang diselenggarakan oleh sekolah tempatnya bekerja maupun atas inisiatif pribadi. Hal ini memang disebabkan karena minimnya sosialisasi gender yang dilakukan oleh pemerintah Kota Surakarta dalam hal ini Dikspora. Selain itu pihak sekolah juga belum memiliki inisiatif untuk mengadakan sosialisasi gender sendiri dengan mendatangkan nara sumber yang mengerti tentang persoalan gender misalnya dari LSM atau Universitas. Persoalan ini disebabkan karena belum begitu populernya sekolah dengan istilah gender sehingga persoalan genderpun belum dianggap sebagai persoalan yang penting untuk dikenalkan pada staf pengajar (guru) atau anak didik (siswa).

Selain itu, hasil wawancara juga menemukan bahwa kata "gender" pun juga belum terbiasa terdengar di sekolah tempat mereka mengajar apalagi dijadikan bahan diskusi dan pembahasan maupun diintegrasikan dalam pengambilan keputusan di sekolah. Namun semua informan mengatakan pernah mendengar kata gender. Gender menurut mereka sering terdengar dalam konteks pembicaraan tentang perempuan seperti misalnya dalam persoalan KDRT (kekerasan dalam rumah tangga) atau jika membicarakan tentang peran atau pemberdayaan perempuan. Artinya 'gender' dalam benak mereka kemudian identik dengan segala persoalan yang menyangkut tentang perempuan. Informan mengetahui kata gender dari majalah/koran (membaca) atau dari perbincangan dengan sesama teman.

Dari hasil wawancara yang dilakukan meskipun mereka mengenal kata "gender" namun masing-masing dari mereka memiliki konsep dan definisi yang tidak sama tentang istilah tersebut. Secara umum, mereka mengartikan gender sebagai persamaan antara laki-laki dan perempuan. Persamaan yang dimaksud adalah kesetaraan karena konsep gender dalam konteks berpikir informan adalah bagaimana perbedaan antara laki-laki dan perempuan. Perbedaan itu berkutat pada persoalan fisik dan kemampuannya, pembagian kerja, tanggung 
jawab dalam keluarga serta peran yang semestinya dilakukan baik itu oleh laki-laki dan perempuan dalam masyarakat.

Contoh tentang perbedaan gender yang diberikan oleh informan juga masih berkutat seputar pembagian kerja secara seksual yang secara kultural dilakukan oleh laki-laki dan perempuan. Dalam pemahaman informan, peran gender yang harus dilakukan oleh perempuan misalnya memasak, mencuci, mengasuh anak, dan segala hal yang berkaitan dengan aktivitas domestik sebagai ibu rumah tangga. Seperti yang dikatakan oleh seorang informan (laki-laki) berikut ini,

"Kalau gender itu ya berkaitan dengan perbedaan antara laki-laki dan perempuan. Misalnya apa yang pantas dikerjakan oleh laki-laki dan perempuan. Kalau tukang becak misalnya, itu ya harus laki-laki karena kalau perempuan kan nggak kuat. Jadi gender bagi saya adalah perbedaan antara laki-laki dan perempuan" (Pak Z).

Atau seperti yang diungkapkan oleh informan lain, seorang guru perempuan:

"Gender adalah kesejajaran atau kesetaraan antara laki-laki dan perempuan. Bagi saya laki-laki dan perempuan sama saja, bisa berkiprah di dunia public. Bedanya hanya pada fisiknya saja. Perempuan lebih lemah, makanya terkadang tidak bisa melakukan hal-hal yang bisa dilakukan oleh laki-laki. Seperti supir truk atau tukang becak itu kan harus laki-laki mbak" (Bu S).

Definisi demikian lazim terdengar dalam masyarakat yang bernuansa patriarkal seperti konteks masyarakat Jawa. Gender popular dengan definisi pembagian kerja atau peran antara laki-laki dan perempuan yang disesuaikan dengan konteks budaya yang ada. Pernyataan seperti yang diungkapkan oleh informan di atas menyoroti konsep gender dengan mereduksinya hanya sebatas pada persoalan biologis fisik semata. Bahwa laki-laki dan perempuan berbeda secara fisik dan hal tersebut kemudian berimplikasi secara sosial budaya terhadap peran-peran mereka. Termasuk di dalamnya jenis-jenis pekerjaan yang secara nilai cultural dianggap cocok untuk laki-laki dan untuk perempuan.

Konsep gender kemudian diartikan oleh informan hanya sebatas pada perbedaan biologis dan fisik yang memiliki implikasi pada aktivitas serta peran sosial seorang laki-laki dan perempuan. Pandangan teori kebudayaan mengemukakan bahwa peran domestik dan publik yang diwariskan berdasarkan norma sosial budaya yang menuntut dan melahirkan sifat feminine dan maskulin. Terlepas dari teori manapun, sifat dan pemilahan peran domestic public merupakan suatu proses budaya yang mengalami kesejarahan yang panjang.

Ace Suryadi (2004:35) menjelaskan bahwa pada kenyataannya organ tubuh laki-laki dan perempuan apabila mendapat latihan fisik yang sama, sejak lahir cenderung akan melahirkan kekuatan yang sama. Perbedaan kemampuan fisik perempuan dan laki-laki 
terjadi, karena sejak anak itu dilahirkan oleh nilai budaya orang tuanya sudah dibedakan. Dengan diarahkan dan dipersiapkan untuk menghadapi peran public dan domestic sehingga dalam perkembangannya secara fisik pun berbeda. Dengan demikian pemahaman informan bahwa tukang becak adalah pekerjaan laki-laki merupakan pemahaman yang dibentuk berdasarkan atas pemahaman gender yang direduksi hanya sekedar sebagai konsep perbedaan antara laki-laki dan perempuan berdasar perbedaan biologis saja.

Selain perbedaan berdasarkan biologis, informan juga memahami konsep gender sebagai perbedaan yang "alamiah" antara laki-laki dan perempuan. Seperti yang diungkapkan oleh seorang guru laki-laki berikut;

"Saya mengenal kata gender. Bagi saya gender berarti perbedaan peran antara laki-laki dan perempuan. Dalam kehidupan sehari-hari contohnya pembagian tugas antara laki-laki dan perempuan. Laki-laki lebih fleksibel karena menggunakan rasio dalam bertindak tetapi perempuan lebih sering menggunakan perasaannya.(Pak R).

Dalam analisis feminisme, gender berbeda dengan sex. Sex adalah definisi yang menjelaskan tentang perbedaan biologis yang mengacu pada kodrat. Dengan demikian tidak bisa dirubah. Cirri-ciri biologis termasuk diantaranya adalah kemampuan hamil, melahirkan dan menyusui pada perempuan yang tidak dimiliki oleh laki-laki. Sementara itu, gender adalah implikasi social budaya dari adanya perbedaan sex.

Sensitivitas gender sangat erat kaitannya dengan pemahaman seseorang akan konsep gender sehingga pemahaman gender yang keliru akan mengakibatkan tidak sensitifnya seseorang terhadap persoalan gender. Dari hasil penelitian hampir semua informan tidak bisa mendefinisikan pengertian atau pemahaman akan sensitivitas gender. Namun ketika ditanyakan tentang persoalan perlakuan yang diberikan kepada murid laki-laki dan perempuan maka muncul jawaban yang beragam. Beberapa diantaranya terangkum dalam kutipan di bawah ini.

"Kalau laki-laki ya berbeda penanganannya dengan perempuan. Kalau anak lakilaki cenderung bandel dan nakal, dikandhani nggak bisa. Biasanya hukumannya ya memang fisik, lari misalnya. Tapi kalau anak perempuan biasanya lebih nurut kalau diberitahu jadi nggak sampai disuruh lari”. (Pak R)

Berdasarkan hasil wawancara ditemukan bahwa para informan yang semuanya adalah guru sekolah dasar masih belum memiliki sensitivitas gender yang mengarah pada tindakan responsif gender. Hal ini disebabkan salah satunya karena bervariasinya makna atau pengertian gender yang mereka miliki. Terlebih lagi, pengertian yang mereka miliki adalah definisi gender yang seringkali justru mengarah pada pengukuhan stereotype gender sehingga 
perilaku yang muncul adalah perilaku yang tidak bisa membedakan mana persoalan gender dan membutuhkan penanganan khusus bagi anak laki-laki dan perempuan dan mana yang bisa disamakan.

\section{Aplikasi Pendidikan Adil Gender}

Pendidikan adil gender merupakan salah satu manifestasi dari kesepakatan dunia tentang deklarasi Education for All yang menjaminkan laki-laki dan perempuan untuk memiliki kesempatan yang sama mengenyam pendidikan. Rutiana (2007:19) menjelaskan bahwa integrasi perspektif adil gender adalah suatu usaha untuk menanamkan nilai-nilai kesetaraan dan keadilan gender pada peserta didik melalui proses pembelajaran di sekolah. Pengintegrasian dilakukan secara khusus dalam proses pembelajaran (yang relevan) kepada peserta didik untuk mencapai standart kompetensi yang diharapkan, dan pada pengelolaan kelas pada umumnya.

Menurut Rutiana (2007:20), perspektif adil gender perlu disisipkan/diintegrasikan ke dalam materi yang relevan karena tidak semua materi pelajaran dapat disisipi nilai adil gender secara langsung dalam pembahasannya. Namun demikian nilai-nilai adil gender tetap dapat diintegrasikan melalui bagian pengelolaan kelas pada waktu penyampaian materi, pembuatan soal berdasar materi, penggunaan alat peraga dan sebagainya. Makna proses pembelajaran yang adil gender adalah proses transformasi ilmu pengetahuan di sekolah yang dilakukan oleh pendidik melalui Proses Belajar Mengajar (PBM), yang memberikan kesetaraan antara laki-laki dan perempuan dalam akses (peluang), partisipasi, kesempatan mengambil keputusan serta manfaat.

Berdasarkan penelitian yang telah dilakukan, semua informan yang merupakan guru pengajar di sekolah dasar sebenarnya telah melakukan atau menerapkan pendidikan adil gender di dalam kelas masing-masing ketika proses kegiatan belajar mengajar (KBM) berlangsung, meskipun mereka tidak mengetahui bahwa yang mereka lakukan adalah salah satu bentuk pendidikan adil gender. Hampir semua informan mengatakan bahwa mereka berusaha keras untuk tidak membeda-bedakan antara murid laki-laki dan murid perempuan dalam hal akademis di dalam kelas. Tidak membedakan artinya adalah memperlakukan murid laki-laki dan perempuan secara sama. Seperti yang diungkapkan berikut:

"Kalau di kelas saya nggak membedakan, misalnya saya suruh maju mengerjakan di depan kelas. Yang bisa siapapun ya maju, nggak bisa ya nggak maju. Mau murid laki-laki yang maju atau murid perempuan sama saja. Yang benar yang salah ya nggak apa-apa kan namanya belajar. Siapa saja boleh mencoba maju" (Bu S). 
"Siapapun di dalam kelas kalau nggak mengerjakan PR tetap ada hukumannya. saya suruh minta maaf di depan kelas. Kalau nakalnya sudah keterlaluan ya saya panggil orang tuanya. Tapi memang biasanya yang banyak nakal itu anak lakilaki jadi memang perhatiannya lebih harus esktra ke anak laki-laki” (Pak Y).

Pola pendidikan adil gender bisa diterapkan baik melalui proses pengajaran, materi yang disampaikan maupun visualisasi dari materi yang disampaikan. Diakui oleh para informan, bagi mereka tidak mudah mengaplikasikan pendidikan adil gender, salah satunya karena ketersediaan bahan ajar yang seringkali masih bias gender. Padahal pengintegrasian perspektif adil gender perlu dilakukan dalam proses pembelajaran.

Rutiana (2007:21-22) menjelaskan perlunya dikembangkan proses pembelajaran yang memasukkan integrasi perspektif adil gender baik karena alasan substantif maupun alasan praktis. Salah satu alasan substantive (berkaitan dengan fakta ilmiah) perlunya proses pembelajaran adil gender dikembangkan karena pada dasarnya baik anak laki-laki maupun anak perempuan memiliki potensi kemampuan yang sama jenisnya. Kemampuan tersebut misalnya logika matematika, kecerdasan visual-spasial, intelegensi kinektik, intelegensi interpersonal, intelegensi intrapersonal dan intelegensi verbal. Sementara itu, alasan praktis (berkaitan dengan kebutuhan sehari-hari) perlunya mengembangkan proses pembelajaran adil gender adalah keperluan penanaman nilai-nilai kesetaraan dan keadilan gender sedini mungkin kepada anak laki-laki dan anak perempuan melalui interaksi pendidik dan peserta didik dalam proses pembelajaran. Nilai-nilai itu akan mempengaruhi cara berpikir anak, dapat terbawa terus sampai dewasa dalam kehidupan sehari-hari. Apabila peserta didik terbiasa mengalami pendidikan dan perlakuan yang adil gender, kelak mereka akan lebih mampu menghadapi tantangan kehidupan yang menuntut perwujudan kemampuan maskulin ataupun feminine yang sebenarnya sama-sama terdapat dalam diri peserta didik.

Berbicara tentang bahan ajar dan materi yang bisa memberikan pendidikan adil gender ternyata sulit ditemui oleh informan dalam penelitian ini. Seorang guru bahasa Indonesia yang diwawancarai mengatakan bahwa bahan ajar yang akan digunakan biasanya ditentukan oleh MGMP (musyawarah guru mata pelajaran) meskipun sebenarnya setiap guru berhak juga untuk menentukan buku pegangan lain. Bahan ajar yang ada disesuaikan dengan kurikulum dan ketentuan pemerintah yang lain. Apabila dalam bahan ajar tersebut masih terdapat materi (percakapan atau tema) dan juga gambar yang bias gender maka menjadi sulit bagi guru untuk mengintegrasikan perspektif gender. Seperti yang diungkapkan berikut:

"Mencari bahan ajar yang tidak membedakan antara laki-laki dan perempuan memang tidak mudah. Kalaupun ada gambar di buku yang sekiranya membedakan, misalnya gambar ibu menggendong anak dan bapak menonton 
televisi biasanya saya hanya mengatakan pada murid-murid bahwa kedua pekerjaan itu seharusnya dilakukan bersama. Kalau ibunya capek menggendong anak ya gantian bapaknya" (Bu S).

"Kalau memperlakukan anak laki-laki dan perempuan ya harus adil alias melihat kebutuhan. Tapi jujur saja saya merasa kesempatan yang dimiliki oleh keduanya sama saja, artinya tidak boleh dilarang hanya karena jenis kelaminnya. Semua pekerjaan bisa dikerjakan oleh laki-laki dan perempuan. Memasak saja bisa dikerjakan oleh laki-laki. Chef-chef dan tukang potong rambut yang terkenal kan malah laki-laki” (Pak Y).

Dengan demikian kreativitas seorang guru memang dituntut untuk dapat mengaplikasikan pendidikan adil gender dalam kelas. Pengertian pendidikan adil gender kemudian menjadi luas tidak hanya menyangkut perlakuan yang sama baik bagi anak lakilaki maupun perempuan namun juga melihat kebutuhan dan kemampuan setiap anak. Menyamakan semua anak juga dianggap tidak adil terlebih apabila pendidik tidak memahami perspektif gender secara menyeluruh.

\section{Kesimpulan}

Artikel ini mendiskusikan tentang persoalan sensitivitas gender guru Sekolah Dasar sebagai upaya perwujudan pendidikan adil gender di Kota Surakarta yang kemudian mengetengahkan berbagai macam hal yang berkaitan dengan pertanyaan penelitian. Secara umum, informan dalam penelitian ini masih belum memahami arti atau konsep gender. Yang mereka pahami dari kata atau istilah gender adalah perbedaan peran antara laki-laki dan perempuan. Namun perbedaan yang mereka pahami masih mengacu pada perbedaan biologis yang memunculkan pembagian kerja berdasarkan jenis kelamin (division of labor based on sex) yang justru mengakibatkan pembakuan peran gender yang ada di masyarakat. Konsep gender juga dipahami sebagai sebuah bentuk kesetaraan antara laki-laki dan perempuan, namun definisi kesetaraan masih juga terbatas pada peran-peran sosial yang dilekatkan pada laki-laki dan perempuan, sehingga walaupun perempuan maju dan bisa meraih hal yang juga diraih oleh laki-laki hendaknya perempuan tidak meninggalkan "kodratnya" sebagai perempuan. Kerancuan pemahaman ini bisa dimengerti karena minimnya sosialisasi gender kepada mereka yang berperan sebagai pendidik. Padahal pemahaman seseorang akan konsep gender akan berpengaruh pada sensitivitas gender yang dimilikinya.

Sensitivitas gender akan berguna manakala ada persoalan-persoalan yang berbasis gender muncul di dalam kelas atau di masyarakat. Sebagian besar informan di dalam penelitian ini tidak memahami apa yang disebut dengan persoalan gender sehingga sulit 
untuk mengukur sensitivitas gender mereka. Namun secara garis besar para informan mengatakan bahwa persoalan gender lebih banyak menimpa anak laki-laki karena merekalah yang kebanyakan berlaku nakal di sekolah. Tidak membiarkan anak laki-laki berlaku nakal bagi mereka adalah suatu perlakuan yang sensitif gender karena biasanya ada pemakluman dari masyarakat apabila anak laki-laki nakal, namun tidak begitu halnya dengan perempuan.

Sensitivitas gender juga berkaitan erat dengan pendidikan adil gender yang diaplikasikan di dalam kelas selama proses belajar mengajar berlangsung. Semua informan dalam penelitian ini mengatakan bahwa mereka tidak pernah membedakan antara murid lakilaki dan perempuan. Sebagian diantara mereka mengkhususkan bahwa pembedaan perlakuan juga diperlukan melihat kasus-kasus yang terjadi. Namun dalam persoalan akademik dan proses pembelajaran maka murid laki-laki dan perempuan memperoleh kesempatan yang sama sebagai peserta didik untuk belajar.

Pemahaman yang sedikit tentang konsep gender ditambah dengan belum mengertinya mereka akan bentuk-bentuk persoalan gender disadari juga turut membuat aplikasi pendidikan adil gender menjadi sedikit tersendat. Terlebih lagi dengan materi serta bahan ajar yang dirasa masih belum mengakomodir kesetaraan dan keadilan gender, menambah kesulitan untuk mewujudkan pendidikan yang adil gender di Surakarta.

\section{Referensi}

Ace Suryadi. 2004. Kesetaraan Gender Dalam Bidang Pendidikan. Bandung: Genesindo.

Budi Rajab. 2004. Pendidikan Sekolah dan Perubahan Kedudukan Perempuan dalam Jurnal Perempuan Vol. 34. Yayasan Jurnal Perempuan.

Ismi Ismi Dwi\& Rutiana dwi Wahyuningsih. 2007. Integrasi Pendidikan Adil Gender Dalam Proses Pembelajaran Di Sekolah Dasar. Surakarta: UNS Press.

Kementrian Pemberdayaan Perempuan RI. Profil Perempuan dan Anak Indonesia Tahun 2007.

Sri Murtiningsih. 2005. Alternatif Pendidikan Freireian: Jalan Keluar Penindasan Terhadap Perempuan dalam Jurnal Perempuan Vol. 44. Yayasan Jurnal Perempuan. . Surakarta dalam Angka Tahun 2007, BPD Kota Surakarta. 